\title{
Between Dialogue and Confrontation: Two Countries - One Profession Project and the Split in Ukrainian Journalism Culture
}

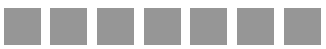 \\ Liudmila Voronova \\ ORCID: 0000-0001-7943-3076 \\ SÖDERTÖRN UNIVERSITY, SWEDEN \\ https://doi.org/10.19195/1899-5101.13.1(25).3
}

\begin{abstract}
In a process of continuously adjusting to and counteracting the circumstances of conflict since 2014, the Ukrainian media community has become polarized (Budivska \& Orlova, 2017). Nygren et al. (2018) observe a confrontation between the ideal of neutrality in coverage and favoring "patriotic journalism" in practice among Ukrainian journalists. This article takes this discussion further and highlights the role of professional journalism associations and international organizations in the struggles within the journalism culture in the situation of conflict. The article uses Ginosar's (2015) interpretation of Hanitzsch's (2007) model of journalism culture and Mouffe's (2013) conceptualization of agonistic vs. antagonistic struggle to discuss the project Two Countries - One Profession is initiated and supported by the OSCE Representative on Freedom of the Media. Finally, it draws on the reactions by the Ukrainian media community.
\end{abstract}

KEYWORDS: conflict, journalism association, journalism culture, objectivity, patriotic journalism, Ukraine.

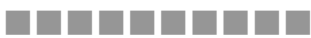

\section{INTRODUCTION}

Since 2014 the Ukrainian media community has been adjusting to and counteracting the circumstances of conflict (e.g. Bolin, Jordan, \& Ståhlberg, 2016; Nygren \& Hök, 2016; Pantti, 2016). On the one hand, there has been a need to counteract external and internal propaganda and act in the de facto war situation. Media professionals have experienced problems with access to and verification of information, as well as with partisanship of information sources (Ojala, Pantti, \& Kangas, 2016; Orlova, 2016). On the other hand, the media market has continued to function, and the media competed for both the audiences' attention and advertisement (Pogorelov, 2017). 
The media community in Ukraine has become polarized in front of the previously unseen challenges brought with the conflict (Budivska \& Orlova, 2017; Dutsyk, 2017; Nygren et al., 2018; Nygren \& Hök, 2016). As articulated by journalists themselves, the media community, roughly speaking, was divided into "adepts of standards" vs. "Glory-to-Ukraine-journalists" (Zinchenko, 2016). This divide has been actively discussed by both media experts and journalists themselves (Dutsyk, 2017). Nygren et al. (2018) study showed that one of the main challenges for Ukrainian journalists has been a conflict between the ideal of neutrality in coverage and favoring "patriotic journalism" in practice. Budivska and Orlova (2017) conducted indepth interviews with journalists who were involved in protest actions in different capacities, and found out that there were three major approaches to the activism vs. professionalism dilemma: some journalists saw a possibility to combine the roles of a journalist and an activist; some saw it as an internal dilemma to be a neutral observer and empathize with the Ukrainian people and the army; and finally, there was a group who criticized the shift towards an activist type of journalism (primarily journalists with experience of working in the international media).

The grounds of this split lie primarily in what strategies media professionals suggest fighting propaganda and meeting other challenges of the conflict: a system of bans and "drawing the curtain", or dialogue and strict adherence to universal journalistic standards and ideals. Thus, one part of the media community called for any available instruments of stopping propaganda. According to Szostek (2018), such state-led and journalist-led corrective actions were related to the presumed influence of the Russian state-controlled media in Ukraine and "based on a conviction that narratives in the Russian media pose an existential threat to their country". These actions included a ban on broadcasting Russian Federation channels on the territory of Ukraine, limited or restricted access to certain media products coming from Russia, as well as attempting the active promotion of Ukrainian interests on non-government-controlled territories. Other instruments included turning the rails towards "patriotic journalism" that is aimed at supporting the interests of the state as a priority, even if it hinders following international professional standards (for a detailed discussion of such actions see Szostek, 2018).

Another part of the media community, while fully agreeing with the risks to the media and journalists caused by the situation of conflict, suggested that many of these instruments of counteracting propaganda should be implemented with caution, as there is a risk of turning the Ukrainian media into a "propaganda machine". Moreover, such attempts to switch to "patriotic journalism" can lead to a risk of losing the audience's trust and interest (see the series of interviews on the topic in Detector Media, 2016). Following the guidelines of international organizations, such as the Organization for Security and Co-operation in Europe (OSCE) and Reporters Without Borders, they suggested that propaganda of all kinds can be fought only with the help of professional standards that should remain the same even in times of conflict, as well as existing, internationally accepted prohibitions 
in law (see e.g. Propaganda and Freedom of the Media, 2015). Access to information, objective coverage of events, discussion of hate speech in the media community, independence from state institutions, free competition on the media market, collaboration with foreign journalists willing to counteract propaganda, were named as efficient ways of fighting propaganda (see Detector Media, 2016).

The project Two Countries - One Profession that is the focus of this analysis, supported this latter view. It suggested, among other things, that the dialogue between professional journalists in Ukraine and Russia should help in counteracting propaganda and diminishing risks and threats for journalists in the current situation. As formulated in the brochure about the project, its aims were "to work together to enhance the safety of members of the media, help maintain professional journalism standards, remind governments about their commitment to respect media freedom and freedom of expression and put an end to gross violations of the rights of journalists and members of the media by state and non-state actors" (Two Countries - One Profession, 2016, p. 1). Yet, this trans-border dialogue was perceived with scepticism and criticism by the part of the media community that stands for "drawing the curtain". With the interesting developments in the short history of the project (which activities started in 2014 and finished in 2018), in this article it serves as an object of study that allows for 1) observing the split in the journalism culture in the situation of conflict, 2) analyzing the role of professional journalism associations and international organizations in shaping the standards and ideals of the professional media community and in promoting or shutting the dialogue between its members, and 3) opening up a discussion about the possibilities of a dialogue-based, agonistic democratic development in the situation of conflict. Two research questions guide the analysis: How does the participation of Ukrainian professional journalism associations and media organizations in the discussion of objectivity vs. patriotic journalism look like on different levels? What is the role of professional journalism associations and international organizations in the struggles within the national culture of journalism in the situation of conflict?

\section{PATRIOTISM VS. OBJECTIVITY BEYOND THE CASE OF UKRAINE: A THEORETICAL FRAMEWORK}

As the critical discussion of the OSCE project is focused on the issue of patriotism and objectivity as a universal journalistic standard, it is important to place the discussion of the project and the situation around it, in the framework of a more general scholarly discussion of journalism culture in the situation of conflict, and, more particularly, of objective vs. patriotic modes of reporting.

According to Zelizer (2005, p. 204), journalism culture is "one of the resources journalists draw upon to coordinate their activities as reporters, photographers, and editors". Hanitzsch (2007) suggests that journalism culture is comprised of ethical ideologies, institutional roles, and epistemological beliefs. Objectivity can 
both be regarded as an ethical ideal and refer to the journalists' epistemological beliefs (Hanitzsch, 2013). If objectivity as an ethical value is seldom questioned by journalists, then in the everyday practices individual journalist's subjective values and practical convenience often challenge the fulfilment of this ideal (Ekström \& Nohrstedt, 1996; Galison, 2015).

There are different ways of approaching the concept of objectivity (see Hopmann, Van Aelst, \& Legnante, 2011). Usually the two key components implied are the obligation to fairness and unbiasedness and the separation of facts from values (Asp, 2014). According to Schudson and Anderson (2009, p. 96), objectivity is viewed as both a norm, and an object of struggle "within the larger struggle over professional jurisdiction". The travelling notion of objectivity (Schudson, 2001) is conceptualized differently in different journalism cultures and is assigned a different value. For example, Robie (2013) argues that "First World" journalism values objectivity, "Second World" journalism - collective agitation, "Third World" journalism - nation-building, and "Fourth World" journalism - self-determination.

Today journalism in general tends to become more and more subjective (Coward, 2013), and objectivity is no longer considered to be the only norm (Schudson \& Anderson, 2009). Some even start to see objectivity as a problem for journalism, and call for alternative forms of reporting - independent but morally engaged (see Harbers, 2016). The "objective mode" of reporting is questioned even more in the situation of conflict - an issue that has a special place in media studies. According to Ginosar (2015, p. 295), "in times of national crisis journalists feel that they have no choice but to express solidarity with their community". This makes journalists leave the "objectivity mode of coverage" and engage in "patriotic behavior": conflicts, especially if happening on the territory of their country or engaging their country, often make journalists give up their "professional identity" and act according to their national, ethnic, or civil identity (Ginosar \& Cohen, 2017; Ruigrok, 2008).

In order to address the phenomenon of patriotic journalism, Ginosar (2015) suggests finding explanations to journalists' behavior in the culture of journalism. He uses Hanitzsch's (2007) model of journalism culture and suggests his own framework for analysis of patriotic behavior of journalists (Budivska \& Orlova, 2017). This framework views national setting, type of media system, and the circumstances as a part of social environment that influences journalism ideology in the situation of conflict. This ideology, in its turn, is comprised of the journalists' visions of their roles in society, values and principles, as well as their conscious or unconscious choice between professional, nationalistic, or universal identities. According to Ginosar (2015, p. 298), "a change in the circumstances, from routine to a national crisis, may drive journalists to change their behavior from objective-impartial behavior to patriotic". Importantly, Ginosar (2015, p. 299) suggests that the same circumstances do not necessarily cause the same behavior among all affected journalists: journalists and journalistic institutions "that conceive their role as adversarial 
and watchdog", in times of national crisis, might "tend to keep the neutral-impartial mode of behavior".

Yet, there is a question whether patriotism and journalism are compatible at all. In his book on global journalism ethics, Ward (2010, p. 214) discusses whether journalists can "be patriotic without compromising the principles of their profession". Ward (2010, pp. 223-224) defines patriotism as "a group loyalty that involves an attitude directed, in varying strengths and in various ways, at a valued object", and suggests distinguishing between extreme and moderate patriotism, one form of the latter being democratic patriotism - "rational love of a democratic society that seeks to realise the human good on all levels".

Ward (2010, p. 234) also suggests that patriotism is receiving a new object "patriotism to humanity and its ethical flourishing". Continuing this idea, Ginosar (2015) reminds that one needs to distinguish between "tribal patriotism", where the "value object" is one's nation and/or country, and "global patriotism", where the "value object" is humanity and the human society as a whole. Yet, Strukov (2016, p. 192) claims that these contradictions - between the patriotic and global perspectives - can be consciously utilized by journalists who wish to "appeal to and manipulate their audiences to gain a geopolitical advantage".

Finally, Ginosar and Konovalov (2015) remind that objectivity has been considered to be "the most acceptable and expected ethical value of journalism" - according to the "Western-liberal-democratic interpretation" of the profession. One needs to keep in mind, on the one hand, the tendency of de-Westernization in media studies, and, on the other, the critique of the Western interpretation of liberal democracy. In order to understand the conflict between the different parts of the media community in Ukraine and see its relevance for the studies of journalism and conflict in general, it may be useful to look at Mouffe's critique of democracy, democratic institutions, and procedures. Mouffe suggests an agonistic model of democracy, where the confrontation between different positions is not eradicated, but ideally "is played out under conditions regulated by a set of democratic procedures accepted by the adversaries" (Mouffe, 2013, p. 9). It is, according to Mouffe (2013, p. 9), not about "overcoming the we/they opposition, but the different way in which it is established". Instead of a consensus - a "conflictual consensus" should be accepted (Mouffe, 2013, p. 8).

\section{PROFESSIONAL JOURNALIST ASSOCIATIONS AND MEDIA ORGANIZATIONS IN POST-2014 UKRAINE}

The conflict between adherents of universal standards and adherents of strict bans and "patriotic journalism" is related to the ideals and practices of journalism, an issue of professional autonomy (Nygren et al., 2018; Nygren \& Hök, 2016). Journalist associations are - at least in the dominant Western ideal of journalism - understood as crucial instruments in maintaining professional autonomy (Lauk \& Nor- 
denstreng, 2017). Yet, even in a democratic context, it can be difficult to separate a common concern for professional journalism from political divisions, when there is an argument between different professional journalist associations within one country (Furman, 2017 on Poland).

In Ukraine, there is a variety of professional associations and organizations for media producers, on different levels, for different types of media, and with different history, sources of funding and functions:

- Associations for journalists and media producers aimed at protecting their professional rights, safety, freedom, providing training for media professionals: National Union of Journalists of Ukraine (since 1959), Independent Media Trade Union of Ukraine (since 2004), Independent Association of Broadcasters (since 2000), Ukrainian Media Business Association (former Ukrainian Association of Periodic Press Publishers, since 2001), Regional Press Development Institute (since 2006);

- Self-regulatory bodies: Commission for Journalism Ethics, and Independent Media Council (since 2015) uniting Center for Democracy and Rule of Law, Institute of Mass Information (IMI), Detector Media, Internews, and Souspilnist Foundation);

- Independent monitoring and expert organizations with a broad spectrum of tasks: Institute of Mass Information (IMI, 1995), and Detector Media (former Telekritika, 2004/2016);

- Expert organizations focused primarily on regulation and media policy: Centre for Democracy and Rule of Law (former Media Law Institute, 2005), and the Reanimation Package of Reforms Coalition (RPR, 2014).

On the one hand, this variety of organizations reflects a vivid and diverse media landscape of the country. The organizations address economic, legal, ethical and other issues of concern for professional producers of local and national, printed and broadcast media. While some organizations have a longer history (like the NUJU), other were created due to the urgent need to react to the most recent challenges (like the Independent Media Council). These different associations and organizations also take different positions in relation to particular topics, such as, for example, a possibility of dialogue with Russian professional associations.

Most of these organizations take an active participation in international projects and many of them primarily rely on funding from abroad, for example, from the European Union (European Commission, Council of Europe), national governments (e.g. Sweden, Great Britain), USAID, IREX, CEDAW, and collaborate with international organizations, such as Internews, Reporters without borders etc. This is important to take into account, as the Two Countries - One Profession project initiated by the OSCE is not something unique when it comes to cooperation between national professional associations and international organizations. Below I will describe the project and the reactions of the different professional associations to it that illustrate how the split in the media community is reflected and partly also 
shaped by the professional associations and expert media organizations in the situation of conflict.

\section{DATA AND METHODOLOGY}

Two Countries - One Profession was a part of the umbrella project Safety of Journalists and Reporting During Crisis (2014-2017) by the OSCE Representative on Freedom of the Media. According to the OSCE, at least 200 individuals and at least 12 institutions participated in it all in all. Two Countries - One Profession consisted of different activities where senior representatives from Ukrainian and Russian professional journalist associations met to discuss ways to improve professional standards and safety of journalists. These included, among other, regular round tables (both closed and public), where action plans, declarations, appeals and public statements were discussed and signed; international conferences organized by the OSCE; a public presentation of the dialogue at the 23rd OSCE Ministerial Council in Hamburg; and a publication of materials from the dialogue (Two Countries - One Profession, 2016). The two key institutional participants of the project were the National Union of Journalists of Ukraine (NUJU) and the Russian Union of Journalists (RUJ), professional associations with the biggest amount of members in their respective countries (see Voronova, forthcoming). Additionally, it included a collaborative project where young journalists from the two countries produced documentary films on the neutral territory of European cities. Beyond these, the OSCE regional conferences and training courses for journalists on the territory of Ukraine - for example, a series of events on the safety of journalists (I attended one of these - "Safety of Journalists: A Basic Standard of Independent Media" held in Odessa in March 2017). Such events were supported by local organizations of the NUJU.

I chose to follow this project as it opened up an opportunity to highlight the role of professional associations in discussions on professionalism and specific risks related to the conflict situation. I had good access to the project materials and meetings due to my acquaintances at the RUJ and the OSCE. Yet, I was aware that the good relations established with the participants of the project could have influenced my perspective in research. I constantly reflected upon my possible biases and tried to find a necessary balance by obtaining information from the critics of the project through interviews and publicly available materials. My academic position, a range of changes that happened at the Russian Union of Journalists since I worked there in 2008-2009, acquaintance with holders of very different opinions in the Ukrainian media community, in my view, have ensured that I had the necessary distance from the participants of the Two Countries - One Profession.

This article presents the results of observations of meetings between the NUJU and the RUJ that took place at the OSCE Ministerial Council 2016 in Hamburg, and at the conference "Media Freedom in Volatile Environments" organized by the 
OSCE Representative on Freedom of the Media in Vienna (June 2017); analysis of four interviews and informal communication with representatives of the Office of the OSCE Representative on Freedom of the Media, the RUJ and the NUJU at these occasions, and additionally in Kyiv and Moscow in 2016 and 2017; and negative and positive reactions to the project by the Ukrainian media community (in online versions of traditional media and on social media). For the analysis a wide range of materials related to the project: brochures, documents, documentaries, and other videos available online were also used. Additionally, eleven interviews with representatives of all of the Ukrainian professional associations and organizations that were listed in the previous section (in Kyiv, in 2016 and 2017) were conducted.

Interviews were conducted in the Russian language, recorded (except for several interviews during which notes were taken) - for which the informants gave their consent, and transcribed. The citations both from the semi-structured interviews and from the media, except for materials originally in English were translated by the author. The focus was specifically on how the different actors (both involved in the project, supporting or criticizing it) reflect upon and explain the relation between objectivity, patriotism, and dialogue.

\section{COUNTERACTING PROPAGANDA OR BETRAYING THE COUNTRY? ANALYSIS OF THE CASE}

According to Andrei Richter, senior adviser of the Office of the OSCE Representative on Freedom of the Media, the main aim of the project was to "counteract propaganda and enmity" by "cooperating in the field of self-regulation, saving journalists held in captivity or as hostages, raising the level of media literacy; youth projects, in which journalists of the two countries [were] reflecting on the issues of reconciliation of the people of the two countries" (interview with Richter, Hamburg, December 2016). While the OSCE was the key initiator and sponsor of the project, all its participants highlighted that other international organizations were supportive to it too. Nadezda Azhgikhina - at the time of the project vice-president of the European Federation of Journalists (2013-2019) and, in its beginning, still one of the Secretaries of the Russian Union of Journalists - highlighted the role of international organizations, such as the OSCE, International Federation of Journalists, European Federation of Journalists, International Press Institute, and Reporters Without Borders, in the search for the language of peaceful communication, counteracting propaganda and hate speech, and in the support of solidarity between professional journalists (Azhgikina, 2016). She specifically pointed to the fact that among the outcomes of the collaboration between the OSCE and Ukrainian and international partners was a publication of a handbook entitled Conflict Sensitive Journalism: Best Practices and Recommendations (2016). This handbook promoted what its authors defined as "good journalism" based on the formula "Accuracy + Impartiality + Responsibility = Reliability" (Conflict Sensitive Journalism, 2016, p. 12). Thus, international organizations, including the OSCE, in a way, promoted the "first world" professional 
values (Robie, 2013) and "global patriotism" with humanity as the main value object (Ginosar, 2015; Ward, 2010) for Ukrainian journalism.

For Sergiy Tomilenko, head of the NUJU, the participation in the project was primary about access to the international community he wanted to inform about the situation for journalists in Ukraine in order to help them. Tomilenko believed that there were particular results of the project - freeing of journalists who were kept in captivity and financial help to internally displaced journalists; according to the participants of Two Countries - One Profession, eight journalists, whose names appeared in the appeals in the project's framework, were released. Also, he specifically warned about the risks of departing from universal standards:

It is a platform for statements and demonstration of adherence to standards, counteraction to propaganda. There are colleagues who oppose the dialogue, believe that it serves the interests of the Kremlin. They believe that we should not enter into a dialogue while the conflict is going on. We advise them to read attentively the statements we are making. We are committed to professional standards. And if colleagues believe that during the times of conflict we must depart from the standards, then we think that this path is dangerous, it can lead to biased journalism (interview with Tomilenko, Hamburg, December 2016).

In the beginning, there were two Ukrainian professional organizations participating in Two Countries - One Profession. The second association - the Independent Media Trade Union of Ukraine (IMTUU) - later left the project, following a conflict between their organization and the other project partners, and a related internal conflict. The former head of the IMTUU, Yuri Lukanov (20112016), was for the continuation of the dialogue in the framework of Two Countries - One Profession. With the new head of the IMTUU, Ihor Chayka (2016-2019), being elected, the association became an active critic of the OSCE project. As Chayka explained:

In the current circumstances, in the situation of war, there cannot be any "play" with the ones who represent the official position of Russia, the official position of the Kremlin. We cannot agree with the information flows that are produced by them, including the Russian Union of Journalists. The Russian Union of Journalists is indeed the official position of the Kremlin, they are not producing any other position (interview with Chayka, Kyiv, April 2017).

Chayka ultimately questioned whether the project could succeed in counteracting propaganda. He proposed that (Russian state) propaganda can only be fought with the help of Ukrainian state mechanisms introducing responsibility for those accused of propaganda and hatred of Ukraine, thus, supporting state-led actions (cf. Szostek, 2018). As for journalist-led actions, Chayka suggested that quality journalism is a reply to the challenges of conflict. Such journalism, according to him, is produced by the national newspaper Den'.

In December 2016, Den' initiated a round table to discuss Two Countries - One Profession in the context of reactions of the professional media community to the propaganda challenges. The specific starting point for the discussion was the EU 
non-legislative resolution calling for counteraction of anti-EU campaigns coming from Russia and Islamist terrorist groups and stating that the EU member states are expected to boost funding for counter-propaganda projects (European Parliament, P8_TA-PROV(2016)0441). As for Russia in particular, the text of the resolution suggests that "the Russian Government is employing a wide range of tools and instruments, such as [...] multilingual TV stations (e.g. $R T$ ), pseudo news agencies and multimedia services (e.g. Sputnik) [...], social media and internet trolls to challenge democratic values, divide Europe, gather domestic support and create the perception of failed states in the EU's eastern neighborhood" (ibid.). Den's point, as formulated in the article written after the round table, was that the NUJU "does not reach' to the agenda raised by the European Parliament. It was as if there was no brazen occupation of the Crimea, and our fighters do not die in the war with Russia, which their 'journalists' call 'civil'” (Rudenko, 2016).

The participants of the round table discussed, among other things, the risks of participating in "collaborationist projects", such as Two Countries - One Profession (see Rudenko, 2016). According to the media experts, invited by Den', Ukraine has its own way when it comes to fulfilling universal professional ideals: as expressed by Sergiy Morugin; "Europeans are trying to lead us in the way that they themselves went when they came out of totalitarian regimes [...]. But we live in other circumstances and have long been traumatised. When they call us for free speech, there should be an understanding that there are special forces against Ukraine that 'dictate' the information field" (see Rudenko, 2016). In a way, the participants of the round table attempted to position Ukrainian journalism in the framework suggested by Robie (2013), with different conceptualizations of professional values in the "First", "Second", and "Third" world, and highlighting the specificity of the Ukrainian context.

Another media expert participating in the round table, Nataliya Ischenko, believed that in the situation with the OSCE project,

the problem is that the OSCE recipe is based on an incorrect diagnosis. The medications we offer are from other diseases. Therefore, in my opinion, you first need to diagnose. And it is precisely at this step that we have the first conceptual difference within the Ukrainian media community, as part of journalists, media activists, and bloggers are convinced that the country is suffering from Russian aggression and created separatist enclaves in our territory, which are guided by the Kremlin; and the others do not understand it and stand on the positions of "pseudo-objectivity". We have not only an armed confrontation on the territory of the Donbas, but the second front, in the information space, opened up against us, so accordingly, no one who works in this environment can be out of conflict [...]. In this field, in Ukrainian journalism there is a confrontation (see Rudenko, 2016).

This confrontation can be understood, following Ginosar (2015), and Ginosar and Cohen (2017) as a confrontation between two communities formed within the national journalism culture challenged by a conflict: one choosing to engage in "patriotic behavior", the other hesitant about or refusing to leave "objectivity mode". 
The discussion about a possibility of dialogue with Russian professional associations in the current situation shifted to a broader discussion about what should be considered a "valued object" (Ward, 2010) and who is allowed to "write a prescription" and define which identity journalists should choose.

After the round table, Den' continued to collect critical opinions about Two Countries - One Profession, and used the criticism against the project as a uniting force for the part of the media community that is against "conscious collaboration with the occupier" and stands for "journalism as a factor of the nation" with a "nation-building mission" (see Lubchak, 2016). As a result, the critics of the project united under the initiative of the "Ukrainian journalism platform", blaming the NUJU, who participated in Two Countries - One Profession, and its supporters, for "sowing conformism in society, blurring values and, in fact, being nothing but preparation of public opinion for capitulation" (see Lubchak, 2016). The appeal of the initiative published in Den' contraposed the EU resolution and the OSCE project, and called on Ukrainian journalists to "take a principle position: to support the decision of the European Parliament, which unambiguously called Russian journalists 'the tool of a hybrid war' against Europe, and to refuse to participate in projects contributing to the spread of Russian propaganda" (see Lubchak, 2016). The head of the IMTUU signed the appeal. Chayka argued:

We first thought that we are in isolation and loneliness, but then, luckily, we got to know that we are not alone, that in Ukraine, there are many individual journalists and organizations who think like us. There appeared an initiative of the "Ukrainian journalism platform" (interview with Chayka, Kyiv, April 2017).

The platform was presented as "the discussion space of independent professional communication on patriotic principles" (see Lubchak, 2016). Yet, the "Ukrainian journalism platform" was not the only space for and the only voice of critique of the NUJU's participation in Two Countries - One Profession. Journalist and film director Oleg Panfilov wrote for the special project "Krym. Realii" by Radio Svoboda: "as it is a part of Ukraine, and not Russia, that is occupied, then how can Russian propagandists and Ukrainian journalists help each other?" (Panfilov, 2016). Victor Nabrusko, one of the NUJU's Secretaries, former head of the National radio of Ukraine and one of the heads of the movement "Rodnaya strana" (Native country), sent a letter to his colleagues at the NUJU, which became public. In this letter, he suggested that collaboration between the NUJU and the RUJ in the framework of the OSCE project is "a vulgar and impudent promotion of the Russian world in the European space" (see Dunja Mijatovic kak..., 2016). Moreover, in June 2018, the NUJU leader (along with some other representatives of the Ukrainian media community) was accused of being a traitor by the Spokesperson of the General Prosecutor of Ukraine for criticism of the state regarding journalists' safety and impunity for crimes against media in the country. Tomilenko received support from the OSCE Representative on Freedom of the Media Harlem Désir, 
who expressed his concern and called on the Ukrainian authorities to "suspend such practices", because "labelling those with critical voices as traitors put them at great risk" (Ukrainian journalists and media..., 2018).

Thus, on the one hand, the idea of working out new principles and standards of patriotic journalism consolidated a part of the media community that felt a need to switch to "patriotic behavior". On the other, the confrontation between the supporters of "patriotic behavior" and those of "objectivity mode" was growing. Even if the contradictions between the patriotic and global perspectives were not utilized by journalists in order to "manipulate their audiences to gain a geopolitical advantage" (Strukov, 2016, p. 192), these contradictions were certainly used in order to gain power over setting the criteria for journalistic professionalism. The fact that the IMTUU supported the "Ukrainian Journalism Platform" and entered, thus, into open confrontation with the NUJU, in a way, institutionalized this split, turning a question of membership in these associations into a political issue for journalists and media producers (cf. Furman, 2017).

This institutional dimension turned the attention of the media community once again to the issue of professional autonomy that is understood as the key concern for journalist associations (Lauk \& Nordenstreng, 2017). Whereas the NUJU related professional autonomy to objective-impartial behavior (cf. Nygren et al., 2018; Nygren \& Hök, 2016), the IMTUU, along with the "Ukrainian journalism platform" rather related it to patriotism and independence from interference by international actors, such as the OSCE.

In this discussion, the NUJU attracted support from other media organizations that together constituted some kind of "alliance" in favor of universal professional standards. Yet, later it received accusations of "distorting the reality" and "corresponding to the interests of certain political circles and oligarchic clans" from a range of Ukrainian professional associations and expert media organizations, including Detector Media and IMI (see Statement by Ukrainian media organizations..., 2018). These organizations called for creating a new professional association that would consolidate the Ukrainian media community "based on independence, accountability, and transparency" (ibid.). Thus, the media community in Ukraine became even more divided. If Hanitzsch's (2007) model of journalism culture is applied, this time what was questioned by the media organizations representing "the other side" (though former "comrades-in-arms") was not the epistemological beliefs dimension (objectivity vs. patriotism), but rather the institutional roles dimension, and particularly the dimension of power distance (cf. Budivska \& Orlova, 2017).

\section{DISCUSSION AND CONCLUSIONS: BETWEEN AGONISM AND ANTAGONISM}

The story of the OSCE project reflects the general problem of journalism culture in the situation of conflict (c.f. Budivska \& Orlova, 2017; Nygren et al., 2018) and an even more general situation of the tensions in and polarization of the intellectual 
elite (Yurchuk \& Marchenko, 2017). The criticism of the OSCE project was largely focused on the issue of patriotism and whether the dialogue with the Russian professional association in the current situation can be considered as betrayal. Based on the case of Two Countries - One Profession, one can say that the confrontation in the Ukrainian media community was observed on several levels (nationalistic vs. patriotic, tribal patriotic vs. global patriotic), and largely caused by an absence of consensus concerning what constitutes patriotism, and what the value object for journalists should be: interests of the nation vs. universal values; interests of the citizens vs. interests of the authorities (cf. Ginosar, 2015). Professional associations and international organizations play an important (if not crucial) role in constructing these definitions. The confrontations between the professional journalist associations in Ukraine confirm Furman's (2017) findings that a concern for professional journalism can be difficult to separate from political divisions.

Is this divide in the Ukrainian media community a specific case or a universal pattern? Two Countries - One Profession allows to once again wonder about the role of international organizations in conflict and post-conflict societies. Today it is common to think of Ukraine in terms of post- or de-colonialism (TörnquistPlewa \& Yurchuk, 2017). Thus, if we follow Robie's (2013) categorisation, it may very well be that the values of collective agitation (especially in the context of postrevolutionary society) and nation building influence the way the media community in Ukraine is approaching the objectivity vs. patriotic journalism dilemma. The OSCE is intervening in the situation with the "first world" ideal of objectivity, bringing the "global patriotism" agenda (Ward, 2010), while some of the local voices are supporting the "tribal patriotism" values. One can criticize this process, as, for example, the cited above participants of the Den' round table did, by assuming a confrontation between the interests of different European institutions (European Parliament vs. OSCE). Another critical perspective can be a post- or a decolonial one, where one can wonder whether these ideals and objectives should be taken for granted, without a critical reflection. For example, Tetyana Lebedeva, the head of the Independent Association of Broadcasters, suggested that the European institutions often use a "mentor tone" and ignore the specificity of the Ukrainian context (interview with Lebedeva, Kyiv, April 2017). In the end, journalists in crisis and post-crisis societies do "not always behave in ways prescribed by a universal norm" (Larssen, 2010, pp. 201-202 on Romanian journalists; see also Budivska and Orlova, 2017). One of the questions for the future research on the Ukrainian media community, thus, can be: What are the implications of the divide in Ukrainian journalism culture for the relations between the international organizations that are funding the Ukrainian professional associations and media organizations supporting different values?

According to Mouffe (2013, p. 7), the agonistic struggle "is the very condition of a vibrant democracy". The described confrontation(s) in the Ukrainian media community may be understood as an agonistic struggle between adversaries, rather 
than enemies. Thus, one may suggest that the growing heterogeneity within Ukrainian journalism culture, in fact, can be interpreted as a conflictual consensus opening up a possibility for a vibrant democracy, rather than an antagonistic struggle of ideologies. However, this assumption only works as long as these different positions are entering a public dialogue. Moreover, one can question whether the attempts to silence the trans-border dialogue with other actors initiated by a third party (as the OSCE project) can be understood as a democratic development.

To sum up, the Two Countries - One Profession case shows that a) professional journalist associations and media organizations in the period of conflict can and do become platforms that both reflect and shape the struggle for professional ideology that happens at this moment; b) international organizations can influence largely the professional ideologies by supporting certain projects, yet they end up in a difficult situation when the journalism culture in the country becomes split. Most importantly: it reminds us once again about the heterogeneity of the national journalism culture that, perhaps, becomes even more obvious in the situation of conflict (cf. Ginosar, 2015). The described case confirms that one and the same circumstances can lead to completely different ideologies and behaviors supported by different professional journalism associations and media organizations in the country.

\section{ACKNOWLEDGMENTS}

This article is a part of the research project "Propaganda and management of information in the Ukraine-Russia conflict: From nation branding to information war" funded by the Foundation for Baltic and East European Studies (2016-2018). The author would like to thank her colleagues at Södertörn University, and especially Gunnar Nygren and Yuliya Yurchuk for their comments and encouragement throughout the research process. Sincere gratitude is expressed to Dariya Orlova (Mohyla School of Journalism) for commenting on an earlier version of this text, and to the two anonymous reviewers for their constructive suggestions. The author would also like to thank all the informants for their time and essential information provided.

\section{REFERENCES}

Asp, K. (2014). News media logic in a new institutional perspective. Journalism Studies, 15(3), 256-270. Azhgikhina, N. (2016). "Dve strany — odna professiya": Zametki na polyakh dokumentov dialoga [Two Countries - One Profession: Notes on the margins of the documents of the dialogue]. Agora, 15, 64-68. Retrieved August 27, 2018, from http://kennankyiv.org/wp-content/uploads/2016/02/Azhgihina_werstka_Agora_V15_final-6.pdf.

Bolin, G., Jordan, P., \& Ståhlberg, P. (2016). From nation branding to information warfare: The management of information in the Ukraine-Russia conflict. In M. Pantti (Ed.), Media and the Ukraine Crisis: Hybrid Media Practices and Narratives of Conflict (pp. 3-18). New York: Peter Lang. 
Budivska, H., \& Orlova, D. (2017). Between professionalism and activism: Ukrainian journalism after the Euromaidan. Kyiv-Mohyla Law and Politics Journal, 3, 137-156.

Conflict Sensitive Journalism: Best Practices and Recommendations. Handbook for Media Practitioners (2016). Kyiv: Kompaniya BAITE. Retrieved September 14, 2018, from https://www.osce.org/ ukraine $/ 254526$ ?download=true.

Coward, R. (2013). Speaking Personally: The Rise of Subjective and Confessional Journalism. Basingstoke: Palgrave Macmillan.

Detector Media (2016, September). Series of interviews with Ukrainian journalists and media experts on the topic of standards vs. patriotic journalism. Retrieved September 14, 2018, from http://detector.media/community/article/118772/2016-09-14-aleksei-bobrovnikov-kritika-poroshenko-vymaryvaetsya-iz-syuzhetov-lichno-rukovoditelyami-telekanalov/.

Dunja Mijatovic kan povod dlya skandala i raskola [Dunja Mijatovic as a cause for scandal and split] (August 4, 2016). Detector media. Retrieved August, 2018, from https://detector.media/medialife/article/117464/2016-08-04-dunya-miyatovich-kak-povod-dlya-skandala-i-raskola/.

Dutsyk, D. (2017, June). Speech at the session "Media self-regulation in times of conflict" at the Media freedom in volatile environments conference. Office of the OSCE Representative on Freedom of the Media, Vienna.

Ekström, M., \& Nohrstedt, S. A. (1996). Journalistikens etiska problem [The Ethical Problem of Journalism]. Stockholm: Svenska Journalistförbundet.

European Parliament (2016). European Parliament resolution of 23 November 2016 on EU strategic communication to counteract propaganda against it by third parties. P8_TA-PROV(2016)0441. Retrieved August 27, 2018, from http://www.europarl.europa.eu/sides/getDoc.do?pubRef=-// $\mathrm{EP} / / \mathrm{TEXT}+\mathrm{TA}+\mathrm{P} 8-\mathrm{TA}-2016-0441+0+\mathrm{DOC}+\mathrm{XML}+\mathrm{V} 0 / / \mathrm{EN}$.

Furman, W. (2017). Journalists' associations in Poland before and after 1980. Media and Communication, 5(3), 79-84.

Galison, P. (2015). The journalist, the scientist, and objectivity. In F. Padovani, A. Richardson, and J. Y. Tsou (Eds.), Objectivity in Science: New Perspectives from Science and Technology Studies (pp. 57-75). Cham: Springer International Publishing.

Ginosar, A. (2015). Understanding patriotic journalism: Culture, ideology and professional behavior. Journal of Media Ethics, 30(4), 289-301.

Ginosar, A., \& Cohen, I. (2017). Patriotic journalism: An appeal to emotion and cognition. Media, War \& Conflict, 12(1), 3-18.

Ginosar, A., \& Konovalov, I. (2015). Patriotism on the internet: Journalists' behavior and user comments. Media, War \& Conflict, 8(3), 368-383.

Hanitzsch, T. (2007). Deconstructing journalism culture: Toward a universal theory. Communication Theory, 17(4), 367-385.

Hanitzsch, T. (2013, August). Presentation at the panel "Why and How Should Journalism Consolidate its Ethical Foundation in a Contemporary Media Landscape Where Everyone Can Produce Something that Resembles Journalism?" at NordMedia 2013 Conference, Oslo.

Harbers, F. (2016). Time to engage. Digital Journalism, 4(4), 494-511.

Hopmann, D. N., Van Aelst, P., \& Legnante, G. (2011). Political balance in the news: A review of concepts, operationalizations, and key findings. Journalism, 13(2), 240-257.

Larssen, U. (2010). Call for Protection: Situating Journalists in Post-Cold War Romania in a Global Media Development Discourse. Doctoral dissertation. Stockholm: Acta Universitatis Stockholmiensis.

Lauk, E., \& Nordenstreng, K. (2017). Journalists' associations as political instruments in Central and Eastern Europe. Media and Communication, 5(3), 67-69.

Lubchak, V. (2016, 25 March). "Mova vorozhnechi” vs latentna bezpryntsypnist' ["Hate speech" vs latent unscrupulousness]. Den'. Retrieved August 27, 2018, from https://day.kyiv.ua/uk/article/ media/mova-vorozhnechi-vs-latentna-bezpryncypnist. 
Mouffe, Ch. (2013). Agonistics: Thinking the World Politically. London: Verso.

Nygren, G., \& Hök, J. (Eds.) (2016). Ukraina och informationskriget: journalistik mellan ideal och självcensur [Ukraine and information war: Journalism between ideals and self-censorship]. Karlstad: Myndigheten för samhällsskydd och beredskap.

Nygren, G., Glowacki, M., Hök, J., Kiria, I., Orlova, D., \& Taradai, D. (2018). Journalism in the crossfire: Media coverage of the war in Ukraine in 2014. Journalism Studies, 19(7), 1059-1078.

Ojala, M., Pantti, M., \& Kangas, J. (2016). Professional role enactment amid information warfare: War correspondents tweeting on the Ukraine conflict. Journalism, 19(3), 297-313.

Orlova, D. (2016). Ukrainian media after the EuroMaidan: In search of independence and professional identity. Publizistik, 61, 441-461.

Panfilov, O. (2016, 13 December). Dve professii OBSE [Two professions of the OSCE]. Krym. Realii. Retrieved August 28, 2018, from https://ru.krymr.com/a/28172410.html.

Pantti, M. (Ed.) (2016). Media and the Ukraine Crisis: Hybrid Media Practices and Narratives of Conflict. New York: Peter Lang.

Pogorelov, O. (2017, 26 October). Zhurnalist ne imeet prava prinimat' na sebya rol' sud'yi [Journalist has no right to assume the role of a judge]. Ukrlife TV. Retrieved August 27, 2018, from http://www. ukrlife.tv/video/politika/zhurnalist-ne-imeet-prava-prinimat-na-sebia-rol-sudi-aleksei-pogorelov.

Propaganda and Freedom of the Media (2015). Non-paper by the Organization for Security and Cooperation in Europe. Retrieved August 27, 2018, from https://www.osce.org/fom/203926.

Robie, D. (2013). "Four worlds" news values revisited: A deliberative journalism paradigm for Pacific media. Pacific Journalism Review, 19, 84-110.

Rudenko, A. (2016, 15 December). Chy ye 'natsionalnyi kharakter' u Natsionalnoi spilky zhurnalistiv? [Does the National Union of journalists have a 'national character'?]. Den'. Retrieved August 27, 2018, from https://day.kyiv.ua/uk/article/media/chy-ye-nacionalnyy-harakter-u-nacionalnoyi-spilky-zhurnalistiv.

Ruigrok, N. (2008). Journalism of attachment and objectivity: Dutch journalists and the Bosnian war. Media, War \& Conflict, 1(3), 293-313.

Schudson, M. (2001). The objectivity norm in American journalism. Journalism, 2(2), 149-170.

Schudson, M., \& Anderson, C. (2009). Objectivity, professionalism, and truth seeking in journalism. In K. Wahl-Jorgensen \& T. Hanitzsch (Eds.), The Handbook of Journalism Studies (pp. 88-101). New York: Routledge.

Statement by Ukrainian media organizations (March 16, 2018). Statement by Ukrainian media organizations regarding the distrust to the leadership of the National Union of Journalists of Ukraine. Detector Media. Retrieved August 27, 2018, from http://detector.media/community/ article/136886/2018-03-16-statement-by-ukrainian-media-organizations-regarding-the-distrust-to-the-leadership-of-the-national-union-of-journalists-of-ukraine/.

Strukov, V. (2016). Digital conservatism: Framing patriotism in the era of global journalism. In M. Suslov \& M. Bassin (Eds.), Eurasia 2.0: Russian Geopolitics in the Age of New Media (pp. 185208). Lanham: Lexington.

Szostek, J. (2018, June). Russia, Ukraine and presumed media influence in international relations. Paper presented at the BISA Annual Conference, Bath.

Törnquist-Plewa, B., \& Yurchuk, Y. (2017). Memory politics in contemporary Ukraine: Reflections from the postcolonial perspective. Memory Studies, 12(6), 699-720.

Two Countries - One Profession (2016). Materials from meetings with representatives of Russian and Ukrainian journalism organizations under the auspices of the OSCE Representative on Freedom of the Media. Retrieved August 27, 2018, from https://www.osce.org/fom/226351? download=true.

Ukrainian journalists and media... (2018). Ukrainian journalists and media must be able to express their opinions openly and freely, says OSCE representative. Retrieved August 27, 2018, from https://www.osce.org/representative-on-freedom-of-media/383478. 
Voronova, L. (forthcoming). Dialogic spaces in the situation of conflict: Stepping stones and sticking points. In S. Maltby, B. O’Loughlin, K. Parry, \& L. Roselle (Eds.), Spaces of War, War of Spaces. New York: Bloomsbury Academic.

Ward, S. J. (2010). Global Journalism Ethics. Montreal: MQUP.

Yurchuk, Y., \& Marchenko, A. (2017). Intellectuals in times of troubles: Between empowerment and disenchantment during the Orange Revolution and Euromaidan. In E. Narvselius \& G. Grinchenko (Eds.), Traitors, Collaborators and Deserters in Contemporary European Politics of Memory: Formulas of Betrayal (pp. 141-168). Cham: Palgrave Macmillan.

Zelizer, B. (2005). The culture of journalism. In J. Curran \& M. Gurevitch (Eds.), Mass Media and Society, 4th ed. (pp. 198-214). London: Hodder.

Zinchenko, L. (2016, 15 September). Tetyana Danylenko: 'Tema sekretnykh tyurem - tse gol, zabytyi i vladoyu, y zhurnalistamy u vlasni vorota' [Tetyana Danilenko: 'The theme of secret prisons...']. Detector Media. Retrieved July 11, 2018, from http://detector.media/community/ article/118808/2016-09-15-tetyana-danilenko-tema-sekretnikh-tyurem-tse-gol-zabitii-ivladoyu-izhurnalistami-uvlasni-vorota/. 